\title{
SOCIOLINGUISTIC ASPECTS OF THE FEMINISATION OF NAMES OF PROFESSIONS IN THE CONTEMPORARY FRENCH LANGUAGE
}

\author{
Alina Iftime ${ }^{1}$ \\ ${ }^{1}$ Lecturer Univ. PhD., Faculty of Psychology and Educational Sciences, Ovidius University of \\ Constanta, ROMANIA, alinaiftime@yahoo.com
}

\begin{abstract}
The access of women in all fields of activity has provoked fierce linguistic polemics on feminisation of names of professions which has represented a wide range of linguistic investigations in France and in many Frenchspeaking countries such as Canada, Belgium and Switzerland.

This paper aims to examine the manifestation of the process of feminisation of names of professions in the French press, in other words, to observe how feminisation of names of professions in the French written media discourse is applied, knowing the fact that the press represents a favourable environment in which two areas conjugate, namely, society and linguistics. Therefore, this study is part of a sociolinguistic framework and will follow two approaches, one regulatory, related to linguistic habits and the other, innovative, revealed by the actual language-based practices that concern the visibility of women on the linguistic level.

This micro research is justified by the assumption already advanced that the media has a very important role in the enrichment of languages, accompanying the evolution of the society by familiarizing the readers with new forms denoting new realities, thereby facilitating their further use.

The objectives of this study are the study in the French press of the feminine forms used to designate women, comparing these forms to those indicated in the feminization guides and the Dictionary of the French Academy, which is the linguistic norm. The second part of the study is dedicated to analysing the procedures used to create the feminine form, in case of finding a lexical variation, but also explaining the factors favouring the option of using a form or another.
\end{abstract}

Keywords: French, sociolinguistics, feminisation, names of profession.

\section{INTRODUCTION}

With the culmination of the parity in politics and the equality of opportunity between men and women, we also observe an acceleration of the feminization in the field of profession names in French from the linguistic point of view. The choice of the theme is motivated by practical reasons, namely, we often encounter hesitations regarding the name of active women, increasingly numerous in various fields. This study wants itself to be enrolled in a sociolinguistic framework, aiming the feminization of names of professions in French, an issue that has stirred spirits in many Francophone countries (French-speaking Belgium, Switzerland, 
Quebec, France).

Any language evolves, mainly under the pressure of the public and media use, therefore, we will focus on the application of the feminization of names of professions in written media discourse. Newspapers consulting seem judicial, since we cannot find a better indicator to see the trends in the current language.

\section{RESEARCH METHODOLOGY}

To contextualize the practice of this micro research, we exposed briefly in the first part, the extra-linguistic reality whose linguistic reflection will be represented by the analysed material. In this presentation, we inserted conclusions about the political debates caused by the feminization as a consequence of parity and rights equality, followed by the presentation of the development of gender issues.

We illustrated the representativeness of women in the workplace and the linguistic reflection in France and other French-speaking countries to show the distinctions from one nation to another, even the francophone ones.

In the practical part, we insisted on studying specific aspects of the use of the feminine form, as feminization processes, rules requiring distribution of females, differences between national feminization guides and the Dictionary of the French Academy.

Our study aims the use of the feminine forms in the French press, fertile ground for lexical innovation. After the registration of the feminine forms, we will study the processes used in the formation of various forms of feminine in this category of nouns. If we notice a lexical variation, we will try to explain which the factors guiding the use of a special form in the practice of the feminization and the causes and consequences of refusing or encouraging the feminization of names of professions in French are.

\section{HYPOTHESIS}

These issues lead us to formulate the following hypothesis:

The first hypothesis is the fact that there could be a wide range of feminine forms corresponding to the same masculine form because inside the guides of feminization of the Francophone countries (Belgium, Switzerland, and Quebec, France) there are suggested forms, distinct from the forms in the Dictionary of the French Academy and then users use one form or another depending on their language needs. Therefore, we want to see how strong indications of feminization guides and Dictionary of the French Academy are accompanied by lexical innovations in daily practice.

From here, the second hypothesis emerges, namely, the use favors the feminization of names of professions as the opposition of the French Academy under the pretext of respecting the language, would create problems, allowing us to study gaps and difficulties that might be created by the refusal of the feminization names of professions by those who break any attempt of innovation of a living language with an evolutionary character.

\section{RESULTS}

We held briefly, in the following lines, the theoretical framework of the large debate which caused the feminist movement. The nineteenth century was marked by attempts to improve the position of women, but only in the twentieth century there is visible progress regarding women's rights, by a decree published on June 26, 1945, in Article 55 of the United Nations Charter, which recognizes women equal to men: "With a view to the creation of conditions of stability and well-being which are necessary for peaceful and friendly relations among nations based on respect for the principle of equal rights and self-determination of peoples, the United Nations shall promote: [...] c. universal respect for, and observance of, human rights and fundamental freedoms for all without distinction as to race, sex, language, or religion" (the International Court of Justice, 1945, p. 11).

So there have been created new rights for women, who are starting to play an important role in the society, changes that were not predictable in the previous centuries. The evolution of women's rights towards an egalitarian life knows an evolution in the society, leading to the adoption of new habits in any field. Since language is a tool which we use to call things on their names, it must adapt itself to social developments and accept the new position occupied by women.

In France, the first discussion about the feminization of language was provoked by three women minister who wanted to be called „Madame la Ministre“. Yvette Roudy, the Minister of women's rights at the time, decided to create a committee of terminology, chaired by Benoîte Groult. The objective of the committee instituted by the Decree of 29 February 1984 as reflected in Article 1, was to deal with the blanks of the 
French language regarding the feminine forms of names of profession and „bring legitimacy to social functions and professions exercised by women" (_, 1984, p. 770).

The Terminology Commission prepared a set of rules allowing the feminization of majority of names of professions, degrees, positions or titles.

In a circular published on March 11, 1986, the Prime Minister Laurent Fabius explains the need to adapt the vocabulary to women's access to different positions and recommends "to ensure the use of such terms“ (, , 1896, p. 4267).

The debate on feminization was resumed in the newspapers Le Monde and Le Figaro during December 1997 - March 1998, on the occasion of the assignment of more women in higher positions of the government, when women realized that the language did not follow the evolution of the society, as in the social hierarchy of that time the masculine form was still used for the profession names, which, in their view, represented an obstacle to the social status of women.

In 1998, the Prime Minister of the time, Lionel Jospin, supported by the President of the Republic, Jacques Chirac, took steps to amend the administrative and official texts, despite the opposition of Government General Secretariat lawyers.

On March 6, 1998, Lionel Jospin submitted a letter to the Government, reminding them the need for using the feminization of names of professions, degrees, positions or titles in official documents of state, and also pointing out the use of the feminization guide realized by the National Institute of the French language. (_, 1998, p. 3565)

So, the importance of this topic is visible, given the debates of politicians and linguists who felt compelled to express their views through circulars and articles in national newspapers.

Language must take into account the effects of the feminization of social structures, but also their sociopolitical context. The problem of feminization of names of professions is not new, but France must catch up with other French-speaking countries such as Quebec, French-speaking Belgium and Switzerland that have issued various texts governing the official administrative use.

But the French Academy is in opposition to the feminization of names of professions, funding its arguments on two essential points: one linguistic, explaining that this intervention could harm the French language, and the other linked to the notion of use, showing that the change in the grammar will not alter the social situation of women.

The French Academy, through its representatives, Claude Lévi-Strauss and Georges Dumézil explains in a statement made on June 14, 1984 that within the other Indo-European languages there is no report of similarity between grammatical gender and natural gender. The French language uses the two genders, the masculine and the feminine and the only way to define these genders is in the distinction marked gender and unmarked gender. The masculine gender is the unmarked gender called extensive as it indicates both male and female, while the feminine is the marked or intensive gender, and it makes the segregation between the sexes (Lévi-Strauss, C. \& Dumézil, G., 1984).

The French Academy concludes that to restore the vocabulary in favour of gender equality, the terms of feminine gender in cases not consecrated in use should be avoided and that it is preferable to use professional names of unmarked gender, if we have a choice.

Elizabeth Dawes (Dawes, 2003, p. 206) shows that the morphological and syntactic structure of the French language provides us with three possibilities of describing professions, such as: the unique gender masculine (un docteur) or, more rarely, the feminine (une doctoresse) -, the minimalist feminisation, by epicenes (un(e) docteur) and the maximalist feminization, by suffixation (une doctoresse). They are individually subject to criticism, so feminists complain that the masculine gender (le ministre) makes women invisible in the language level, even in the society, while the French Academy claims that the unique feminine gender (sage-femme) excludes men. The distinction to the marked gender indicated by article (epicene) is deleted on plural (le ministre, la ministre, les ministres). In addition, the feminine forms often have pejorative connotations forms (poétesse) or create embarrassing contexts, with sexual notes (entraîneuse).

In the table below, we compare on a sample that we consider representative, the differences between some feminine nouns as they appear in the indicative lists of the feminization guides in Quebec, Belgium, France and Switzerland. 


\begin{tabular}{|c|c|c|c|c|}
\hline $\begin{array}{l}\text { Au féminin: guide } \\
\text { de féminisation } \\
\text { des titres de } \\
\text { fonction et des } \\
\text { textes } \\
\text { QUÉBEC } \\
1991\end{array}$ & $\begin{array}{l}\text { Mettre au féminin } \\
\text { BELGIQUE } \\
1994\end{array}$ & $\begin{array}{l}\text { Femme, j'écris ton } \\
\text { nom... } \\
\text { FRANCE } \\
1999\end{array}$ & $\begin{array}{l}\text { Écrire les genres } \\
\text { SUISSE } \\
2001- \\
\text { Le nouveau } \\
\text { Dictionnaire } \\
\text { féminin - } \\
\text { masculin des } \\
\text { professions, } \\
\text { des titres et des } \\
\text { fonctions } \\
\text { Thérèse Moreau } \\
\text { 1999 }\end{array}$ & $\begin{array}{l}\text { Dictionnaire } \\
\text { de l'Académie }\end{array}$ \\
\hline Une auteure & Une auteur & $\begin{array}{l}\text { Un auteur, une } \\
\text { auteure }\end{array}$ & Une autrice & Auteur - n. m. \\
\hline Une chef & Une chef & Un chef & Une cheffe & Chef - n. m. \\
\hline Une consule & Une consule & Un consule & Une consulesse & Consul-n.m. \\
\hline Une écrivaine & Une écrivain & Une écrivaine & Une écrivaine & $\begin{array}{l}\text { Ecrivain - n. } \\
\mathrm{m} \text {. }\end{array}$ \\
\hline Une ingénieure & Une ingénieur & $\begin{array}{l}\text { Un ingénieur, une } \\
\text { ingénieure }\end{array}$ & Une ingénieure & $\begin{array}{l}\text { Ingénieur - } \mathrm{n} \text {. } \\
\mathrm{m} \text {. } \\
\text { Une femme } \\
\text { ingénieure }\end{array}$ \\
\hline Une médecin & Une médecin & Un médecin & Une médecin & $\begin{array}{l}\text { Médecin - } \mathrm{n} \text {. } \\
\mathrm{m} . \\
\text { Une femme } \\
\text { médecin }\end{array}$ \\
\hline Une poète & $\begin{array}{l}\text { Une poète, une } \\
\text { poétesse }\end{array}$ & $\begin{array}{l}\text { Un poète, une } \\
\text { poétesse }\end{array}$ & Une poétesse & Poète - n. m. \\
\hline Une professeure & $\begin{array}{l}\text { Une professeur, une } \\
\text { professeur }\end{array}$ & $\begin{array}{l}\text { Un professeur, une } \\
\text { professeur }\end{array}$ & Une professeure & $\begin{array}{l}\text { Professeur - } \\
\text { n. m. }\end{array}$ \\
\hline
\end{tabular}

Fig. 1. Feminine nouns in the guide of feminization

The official guides present the feminine forms that comply with the grammar rules. These guidelines were drawn up after years of hesitation and linguistic and socio-cultural debates and they also brings together the exact rules to help the speakers to acquire more easily the new forms of feminine nouns.

In the following table, we inserted the same nouns and their occurrences in the press, in the same countries:

\begin{tabular}{|l|l|l|l|}
\hline QUÉBEC & BELGIA & FRANȚA & ELVEȚIA \\
\hline Une auteure & Une auteur & Un auteur & Une autrice \\
\hline Un chef & Une chef & Un chef & Une cheffe \\
\hline Une consule & Une consule & Un consul & Une consulesse \\
\hline Une écrivaine & Une écrivain & Un écrivain & Une écrivaine \\
\hline Une ingénieure & Une ingénieur & Un ingénieur & Une ingénieure \\
\hline Une médecin & Une médecin & Un médecin & Une médecin \\
\hline Une poète & Une poète & Un poète & Une poétesse \\
\hline Une professeure & Une professeur & Un professeur & Une professeure \\
\hline
\end{tabular}

Fig. 2. Feminine nouns in the francophone press

Analysing these tables, we can remark that France still resists to feminization, the French keeping the masculine form to express the feminine. Although feminization hasn't won the favours of the French Academy, we can observe that journalists apply more frequently, but not systematically, modern rules of 
feminisation of names of professions.

While Belgium is closer to France in terms of its conception about feminization, the Swiss who want the amendment to be maximal, adopt the suffixation to express the feminine, but also the innovations such as in the case of cheffe, but also the conservatism as autrice, consulesse, écrivaine. poétesse, preferring the feminine forms distinguished not only in writing, but also orally.

The Canadians prefer the minimalist form, only graphics with the addition of -e: auteure, chercheure, docteure, the forms in -eure being described by the author of Nouveau Petit Robert Dictionary, Josette ReyDebove as "militant barbarisms“ (Rey-Debove, J., 1998, p.16). This phenomenon might be explained by the influence of English, which tends to levelling genders, as Elisabeth Dawes sustains (Dawes, 2003, p. 209). Itsuko Fujimura (2005) also infers we must realize that, in our multicultural world, the influence of languages among themselves is common.

Belgium differs from Canada and Switzerland in opting for the epicene forms, for the nouns ending in -eur: un(e) auteur, un(e) ingénieur, un(e) docteur, un(e) professeur. So, for Josette Rey-Debove (The Belgians are closer than the Canadians to the French sensitivity „not auteure with $-e$, but une auteur being in line with abstract nouns: la frayeur et la pesanteur etc." (Rey-Debove, 1999, p. 60).

The table containing the names taken from the press allows us to observe that there are as many forms as many linguistic communities (un auteur, une auteur, une auteure, une autrice). Most of the times, Canada is alloyed either to Switzerland (écrivaine, ingénieure, professeure) or to Belgium (chef, consule, poète), but we also notice the situation in which the three countries have a unanimous view (médecin). Michèle LenoblePinson (Lenoble-Pinson, 2006, p. 644) argues that the Canadians sometimes tend to depart from the traditional rules because they would want to standardize how to make the feminine by adding $-e$ systematically to the masculine form, except when the noun already ends in that vowel (chercheure).

\section{CONCLUSION}

We could notice that the evolution of the feminisation of French found inspiration and motor in the debates and in the progression of extra linguistic feminisation, as language evolves in parallel with the status of women in the society. We found the ambitions of womențs emancipation and their tendency to refuse using the masculine to designate their profession.

At first glance, the feminisation of names of professions may seem only a matter strictly related to grammar, but in fact, it is a phenomenon deeply rooted in feminism. Given that the position of women never ceases to evolve, we anticipate that we will witness in the future to the metamorphosis of the vocabulary. Specialists in linguistics expressed their view that the French should seek and accept the changes occurring in the society. Elisabeth Dawes (Dawes, 2003) states that, as a linguistic system, the French language is neutral, leaving to users the care of make their own choice, the involving constraints are not due to the language, but to the speakers imposing their ideology in the language. And therefore, the feminisation of names of professions is not a linguistic problem, but a problem of society, not linked to morphological forms of the words, but to the social status of their referent, because we can say une secrétaire, but we cannot say une secrétaire d'État.

A comparison of the use of the terms designing prestigious professions in France, Belgium, Switzerland and Canada reveals significant regional differences and suggests that the internal structure of the French language allows a great latitude to speakers in the creation of feminine names of professions.

But there are, of course, conservative experts who oppose any change for fear of negative influences on the language that could be exercised by these radical changes. But in our opinion, the language is a reflection of the trends in the human life, and therefore we should enrich the vocabulary with new words to help the speakers to express themselves more easily and to "translate better" the new extra-linguistic context.

The second hypothesis discussed the formal restrictions and the barriers that do not allow us to form a feminine noun according to the existing rules. If the linguists do not find a feminine equivalent of the masculine noun relating to a profession, they must create a new form, not yet existing or they should use an existing noun, but which has a different meaning. In this situation, it may happen that speakers reject the created form and refuse to use it.

Even if sometimes, the society considers that feminists exaggerate, we believe that the right way to name a person represents the only possibility to give him / her a good representation. 


\section{REFERENCE LIST}

(3 March 1984). Décret $n^{\circ} 84$ - 153 du 29 février 1984 portant sur création de la commission de terminologie relative au vocabulaire concernant les activités des femmes. Journal officiel. http://www.legifrance.gouv.fr/jopdf/common/jo_pdf.jsp?numJO=0\&dateJO=19840303\&numTexte=\&pa geDebut=00770\&pageFin $=$

18 March 1986). Circulaire du 11 mars 1986 relative à la féminisation des noms de métier, fonction, grade ou titre. Journal officiel de la République française. http://discriminationsegalite.cidem.org/documents/texte_de_loi_sur_la_feminisation_des_noms_de_metier.pdf

8 March 1998). Circulaire du 6 mars 1998 relative à la féminisation des noms de métier, fonction, grade ou titre. Journal officiel de la République française.

http://www.legifrance.gouv.fr/jopdf/common/jo_pdf.jsp?numJO=0\&dateJO=19980308\&numTexte=035 65\&pageDebut=03565\&pageFin $=$

Dictionnaire de l'Académie française, neuvième édition, version informatisée. http://atilf.atilf.fr/dendien/scripts/generic/cherche.exe?15;s=1654505280

Becquer, A. et all. (1999). Femme, j'écris ton nom ... Guide d'aide à la féminisation des noms de métiers, titres, grades et fonctions. Préface de Lionel Jospin. Paris: CNRS-InaLF. 124 p. http://www.culture.gouv.fr/culture/dglf/ressources/feminisation.pdf

Conseil supérieur de la langue française. (1994). Mettre au féminin: Guide de féminisation des noms de métier, fonction, grade ou titre. Bruxelles: Service de la langue française, 1994.79 p. http://www2.cfwb.be/franca/femini/feminin.htm

Dawes, E. (2003). La féminisation des titres et fonctions dans la Francophonie: de la morphologie à l'idéologie. Ethnologies, vol. 25, nr. 2, p. 195-213. http://id.erudit.org/iderudit/008054ar

Fujimura I. (2005). La féminisation des noms de métiers et des titres dans la presse française (1988-2001). Mots. Les langages du politique, 78. http://mots.revues.org/355

Lenoble-Pinson, M. (2006) Chercheuse? chercheur? chercheure? Mettre au féminin les noms de métier et les titres de fonction. Revue belge de philologie et d'histoire, tome 84, fasc. 3. Langues et littératures modernes - Moderne taal en litterkunde. pp. 637-652.

Lévi-Strauss, C. \& Dumézil, G. (1984). Déclaration faite par l'Académie française en séance du 14 juin 1984. http://www.academie-francaise.fr/actualites/feminisation-des-titres-et-des-fonctions

Moreau, T. (2001). Écrire les genres. Guide romand d'aide à la rédaction administrative et législative épicène. Genève: État de Genève, DF-SPPÉgalité-CLDE. 42 p. http://www.fr.ch/bef/files/pdf1/guide_epicene.pdf

Office de la langue française. (1991). Au féminin: guide de féminisation des titres de fonction et des textes. Québec: Publications du Québec. 35 p. http://www.oqlf.gouv.qc.ca/ressources/bibliotheque/feminin/aufeminin_final.pdf

Rey-Debove, J. (1999). Féminisation de la langue: une affaire d'usage. Le français dans le monde, 304 : 59 60.

Rey-Debove, J. (1998). Madame "la" ministre. Le Monde. 14 January.

The International Court of Justice. (1945). Charter of the United Nations and Statute. San Francisco. https://treaties.un.org/doc/publication/ctc/uncharter.pdf 